\title{
DATA MINING DENGAN ALGORITMA APRIORI PADA RDBMS ORACLE
}

\author{
Dana Sulistiyo Kusumo ${ }^{1}$, Moch. Arief Bijaksana ${ }^{2}$, Dhinta Darmantoro ${ }^{3}$ \\ Jurusan Teknik Informatika Sekolah Tinggi Teknologi Telkom \\ 19ana@stttelkom.ac.id, ${ }^{2}$ arifb@telkom.co.id, ${ }^{3}$ dhinta@ $\underline{\text { stttelkom.ac.id }}$
}

\begin{abstract}
Abstrak
Data mining merupakan proses analisis data menggunakan perangkat lunak untuk menemukan pola dan aturan (rules) dalam himpunan data. Data mining dapat menganalisis data yang besar untuk menemukan pengetahuan guna mendukung pengambilan keputusan. Dalam penelitian ini akan dibahas Association Rule sebagai salah satu fungsi data mining yang diimplementasikan menggunakan Algoritma Apriori. Akan dianalisis pula dua teknik penghitungan support di candidate generation pada Algoritma Apriori, yakni : K-way dan 2 Group-By pada tiga sampel dataset dengan atribut transaksi id dan item. Pada penelitian ini terlihat bahwa permasalahan penghitungan support di candidate generation merupakan bottleneck dari Algoritma Apriori dimana perbaikan Algoritma Apriori ditekankan pada candidate generation dan efektivitas dari Algoritma Apriori. Penelitian ini dilakukan pada RDBMS Oracle dengan memanfaatkan tools TKPROF untuk mengukur performansi query berdasarkan operasi I/O pada penghitungan support di candidate generation. Hasil penelitian membuktikan bahwa metode support counting K-way lebih baik daripada Two Group-by.
\end{abstract}

Kata Kunci : Data Mining, Association Rule, Algoritma Apriori, candidate generation, K-way, 2 Group-By

\begin{abstract}
Data Mining is a data process analysis using software for finding pattern and rule in dataset. Data Mining could analyze large dataset to obtain knowledge as a pattern having meaning for making decision in management level for business organization. This paper discusses Association Rule as one function of data mining implemented using Apriori Algorithm. Two counting techniques of support in candidate generation in Apriori algorithm, i.e. K-way and 2 group-By on three dataset samples with transaction attribute id and item, would also be discussed. This research reveals that the problem of support counting in candidate generation is a bottleneck of Apriori algorithm, where Apriori Algorithm fitting is emphasised on candidate generation and effectiveness of Apriori Algorithm. This research was done on RDBMSS Oracle utilizing TKPROF tools to measure query performance based on I/O operation on support counting in candidate generation. The result shows that $\mathrm{K}$-way support counting method is better than Two Group-by method.
\end{abstract}

Keywords : Data Mining, Association Rule, Apriori algorithm, support, candidate generation, K-way, 2 Group-By and RDBMS.

1. Pendahuluan

Data mining merupakan suatu proses pendukung pengambil keputusan dimana kita mencari pola informasi dalam data. Pencarian ini dapat dilakukan oleh pengguna, misalnya dengan menggunakan query (dalam kasus ini sangat sulit dilakukan) atau dapat dibantu dengan suatu aplikasi yang secara otomatis mencari pola informasi pada basis data. Pencarian ini disebut discovery. Discovery adalah proses pencarian dalam basis data untuk menemukan pola yang tersembunyi tanpa ide yang didapatkan sebelumnya atau hipotesa tentang pola yang ada. Dengan kata lain aplikasi mengambil inisiatif untuk menemukan pola dalam data tanpa pengguna berpikir mengenai pertanyaan yang relevan terlebih dulu.

Salah satu bentuk pola yang dapat dihasilkan data mining adalah association rule. Association Rule dapat digunakan untuk menemukan: hubungan atau sebab akibat.
Association rule memiliki bentuk LHS $\Rightarrow$ RHS dengan interpretasi bahwa jika setiap item dalam LHS (Left Hand Side) dibeli, maka item dalam RHS (Right Hand Side) juga dibeli. Association rule dapat dihasilkan dengan Algoritma Apriori. Salah satu penggunaan Association rule adalah mendukung pengambilan keputusan dalam bidang pemasaran, misalnya untuk mengetahui pola pembelian pelanggan, penentuan tata letak barang dan lain-lain.

Salah satu obyek untuk data mining adalah RDBMS. Umumnya data mining dilakukan pada penyimpanan data berukuran besar. Dalam penelitian ini akan dilakukan pengujian terhadap proses penghitungan support dalam implementasi data mining pada RDBMS.

Analisis terhadap teknik penghitungan support perlu dilakukan karena faktor :

1. Banyaknya kandidat frequent-itemset yang dihasilkan sebagai input terhadap penghitungan support,

2. Scan/pembacaan record pada RDBMS. 
Kedua faktor diatas dapat mempengaruhi jalannya pemrosesan query pada RDBMS.

Penelitian ini dilakukan dengan tujuan untuk menerapkan Algoritma Apriori dengan teknik support counting K-way dan 2 Group-By, mencari Association Rule pada RDBMS Oracle, dan mengimplemantasikannya dalam bentuk perangkat lunak. Analisis Algoritma Apriori didasarkan pada hasil pengukuran performansi proses query pada teknik support counting K-way dan 2 Group-By menggunakan tools TKPROF pada RDBMS Oracle.

Batasan masalah untuk penelitian ini adalah sebagai berikut :

1. Data yang digunakan merupakan tabel relasional

2. Hanya digunakan tiga dataset sebagai bahan pengukuran untuk analisis pemrosesan query

\section{Data Mining}

\subsection{Definisi Data Mining}

Pengertian Data Mining atau Knowledge Discovery in Database menurut William J. Frawley, Gregory Piatetsky-Shapiro dan Christopher J. Matheus [10]:

Data Mining atau Knowledge Discovery in Database( KDD ) adalah penyaringan data secara implisit dimana sebelumnya tidak diketahui terdapatnya informasi yang potensial.

\subsection{Fungsi dan Tugas Data Mining}

Data mining menganalisis data menggunakan tool untuk menemukan pola dan aturan dalam himpunan data. Perangkat lunak bertugas untuk menemukan pola dengan mengidentifikasi aturan dan fitur pada data. Tool Data mining diharapkan mampu mengenal pola ini dalam data dengan input minimal dari user.

Dalam penelitian ini pembahasan Data Mining diklasifikasikan dalam fungsi Association.

\subsection{Association Rule}

Tipe pola yang penting yang dapat ditemukan dari basis data adalah sebuah aturan. Association rule mempunyai bentuk LHS $\Rightarrow$ RHS dengan interpretasi jika setiap item dalam LHS dibeli maka sepertinya item dalam RHS juga dibeli. Dua pengukuran penting untuk sebuah rule adalah support dan confidence. Kita dapat menghitung semua association rule dengan ambang support dan confidence masukkan pengguna dengan postprocessing frequent-itemset.

Secara umum Association Rule mempunyai bentuk : LHS $\Rightarrow$ RHS, dimana LHS dan RHS adalah himpunan item; jika setiap item-item dalam LHS terdapat dalam transaksi maka item-item di RHS juga terdapat dalam transaksi.
Ada dua aturan pengukuran untuk 'association rule' : 1. Support

Support untuk himpunan item adalah prosentase transaksi yang berisi semua item-item ini. Support untuk aturan LHS $\Rightarrow$ RHS di-support untuk himpunan item-item LHS $\cup$ RHS.

\section{Confidence}

Pertimbangkan transaksi yang berisi semua item dalam LHS. Confidence untuk rule : LHS $\Rightarrow$ RHS adalah prosentasi transaksi yang juga terdiri semua item-item dalam RHS.

Lebih tepatnya, misalkan sup (LHS) adalah prosentase transaksi yang berisi LHS dan sup (LHS $\cup$ RHS) adalah prosentase transaksi yang berisi LHS dan RHS, maka confidence rule: LHS $\Rightarrow$ RHS adalah $\sup ($ LHS $\cup$ RHS )/sup (LHS ).

Permasalahan Association Rule dapat dikomposisikan menjadi dua sub masalah, yaitu:

1. Penemuan semua kombinasi item-item, yang disebut frequent-itemset, yang support-nya lebih besar daripada minimum support.

2. Gunakan frequent-itemset untuk membangkitkan aturan yang diinginkan. Idenya adalah, katakan, $\mathrm{ABCD}$ dan $\mathrm{AB}$ sering muncul dalam transaksi, maka aturan $\mathrm{AB} \Rightarrow \mathrm{CD}$ akan dipenuhi jika perbandingan antara support(ABCD) terhadap support $(\mathrm{AB})$ minimum sebesar minimum confidence. Semua rule akan mempunyai minimum support karena ABCD sering muncul dalam transaksi.

\subsection{Algoritma Apriori}

Langkah yang membutuhkan pemrosesan lebih adalah penemuan frequent-itemset. Algoritma untuk menemukan frequent-itemset berdasar pada sifat frequent-itemset:

Sifat Apriori : Setiap subset frequent-itemset harus menjadi frequent-itemset [12].

Algoritma Apriori untuk menemukan frequentitemset merupakan iterasi pada data. Pada iterasi ke$\mathrm{k}$ ditemukan semua himpunan item-item yang mempunyai $\mathrm{k}$ item yang disebut k-itemset. Setiap iterasi terdiri dari dua tahap.. Pertama, adalah tahap pembangkitan kandidat (candidate generation) dimana himpunan semua frequent $(k-1)$-itemset $F_{k-1}$ yang ditemukan pada pass ke- $(k-1)$ digunakan untuk membangkitkan kandidat itemset $C_{k}$. Prosedur pembangkitan kandidat menjamin bahwa $C_{k}$ adalah superset dari himpunan semua frequent k-itemset. Kemudian data di-scan dalam tahap Penghitungan Support (Support Counting). Pada akhir pass $C_{k}$ diperiksa untuk menentukan kandidat mana yang sering muncul, menghasilkan $F_{k}$. Penghitungan support berakhir ketika $F_{k}$ atau $C_{k+1}$ kosong.

Untuk membangkitkan rule akan dibangkitkan lebih dahulu candidate rule. Candidate rule berisi semua kemungkinan rule yang memiliki support > minimum support karena input candidate rule adalah frequent-itemset. Kemudian candidate rule akan di- 
join dengan tabel $F$ untuk menemukan support antecedent. Confidence rule dihitung dengan cara membandingkan support rule dengan support antecedent rule. Hanya rule yang mempunyai confidence > minimum confidence yang disimpan dalam tabel rule (tabel $R$ ).

\section{Pengukuran data penelitian}

Untuk menganalisis teknik penghitungan support $K$-way dan 2 Group-By pada Algoritma Apriori digunakan 3 sampel dataset dengan atribut transaction identifier (id) dan item identifier (item), dimana untuk setiap id terdapat beberapa item. Deskripsi data yang digunakan dalam penelitian ini diperlihatkan pada Tabel 1 di bawah ini.

Tabel 1. Data Penelitian

\begin{tabular}{|c|c|c|c|c|c|}
\hline I & II & III & IV & V & VI \\
\hline A & 102 & 27 & 9 & 5 & 3,78 \\
\hline B & 27701 & 5840 & 16 & 9 & 4,74 \\
\hline C & 97084 & 11680 & 32 & 18 & 8,31 \\
\hline
\end{tabular}

Keterangan judul kolom :
I : Dataset
IV : $\sum$ Transaksi
II : $\sum$ Record
$\mathrm{V}: \sum$ Item
III : $\sum$ Group
VI : Max. Itemset

VII : $\sum$ Rata-rata item per transaksi

Untuk menganalisis kedua teknik penghitungan support di atas digunakan tools TKPROF untuk mengetahui besarnya operasi I/O (disk) pada eksekusi Algoritma Apriori. Pengukuran terhadap operasi I/O (disk) dijadikan suatu parameter karena operasi I/O (disk) mendominasi waktu total eksekusi query pada RDBMS. Pada Gambar 1, 2, dan 3 ditampilkan hasil pengukuran operasi I/O (disk) pada tiga sampel dataset.

Performansi kedua metode support counting dipengaruhi oleh besarnya minimum support dan data yang digunakan. Jika minimum support kecil maka semakin banyak kebutuhan I/O dibandingkan dengan jika minimum support besar. Hal ini disebabkan karena jumlah record yang diproses lebih banyak. Data yang di-mining juga memberi pengaruh terhadap jumlah record yang diproses. Besarnya data yang di-mining berbanding lurus terhadap jumlah record yang diproses. Sehingga berdasar hasil pengukuran, K-way secara umum lebih baik daripada Two Group-by, K-way karena lebih sedikit dalam melakukan operasi I/O dibandingkan dengan Two Group-by.

\section{Analisis Algoritma Apriori}

Berdasarkan teori pemrosesan query, Two Group-by berbentuk nested query dengan inner query dan outer query-nya berbentuk group by. Pada pemrosesan query Two Group-by, Inner group-by melakukan sorting menggunakan banyak relasi antara. Hasil query dari inner query kemudian menjadi masukan outer query. Pada Two Group-by agregasi dilakukan dua kali.

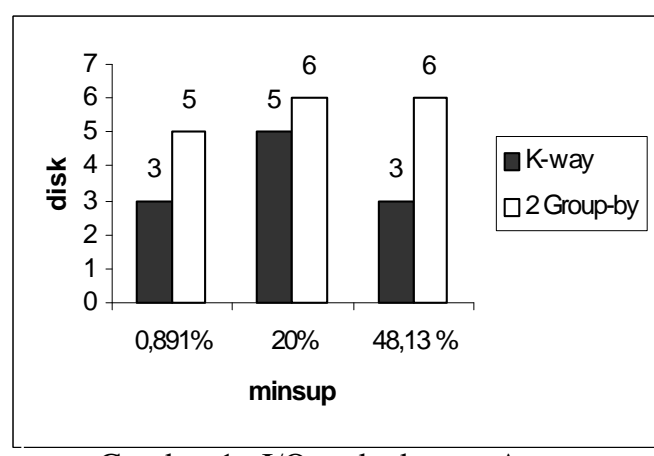

Gambar 1. I/O pada dataset A

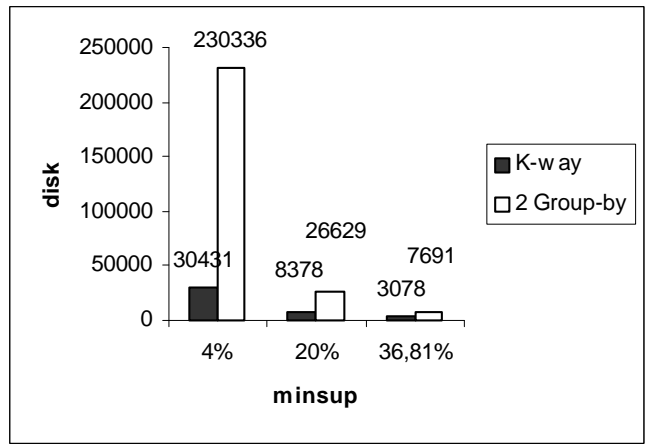

Gambar 2. I/O pada dataset B

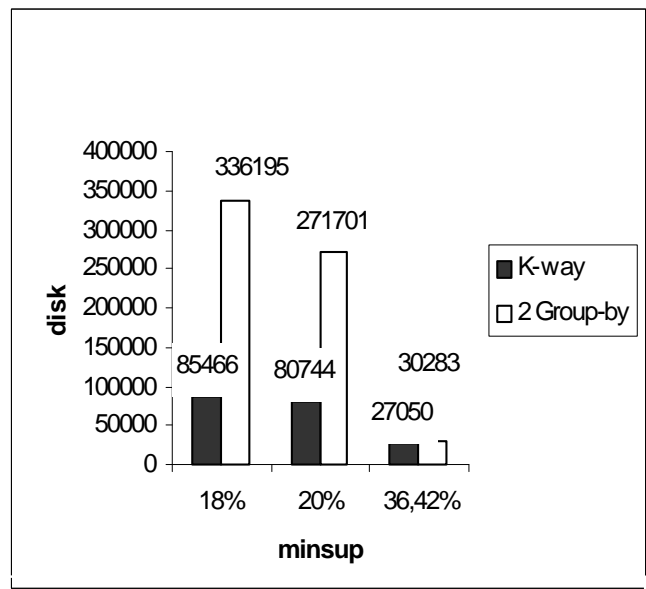

Gambar 3. I/O pada Dataset C

Pemrosesan query pada K-way lebih sedikit menggunakan relasi antara yang berupa sorting dibandingkan Two Group-by. Pada K-way agregasi hanya dilakukan sekali.

Berdasar pemrosesan query diatas, K-way lebih sedikit dalam melakukan sorting dan operasi agregasi dalam mengeksekusi query dibandingkan Two Group-by.

Algoritma Apriori untuk menemukan frequentitemset merupakan iterasi pada data. Algoritma Apriori dimulai dengan pembangkitan kandidat itemset. Pembangkitan itemset menjamin $\mathrm{C}_{\mathrm{k}}$ adalah superset dari himpunan semua frequent $k$-itemset. 
Kemudian data di-scan dalam tahap Penghitungan Support (Support Counting).

insert into $F_{k}$ select item $1, \ldots$, item ${ }_{k}$, count $\left.{ }^{*}\right)$ from ( select item $_{1}, \ldots$, item ${ }_{k}$, count ${ }^{\star}$ ) From Xact, $C_{k}$ where item $=C_{k}$.item ${ }_{1}$ or...... item $=C_{k}$. item ${ }_{k}$ group by item ${ }_{1}, \ldots$, item ${ }_{k}$, tid having count $\left({ }^{*}\right)=k$ ) group by item ${ }_{1}, \ldots$, item ${ }_{k}$ having count $\left({ }^{*}\right)>$ : minsup

Gambar 4. Penghitungan support 2 Group-by

insert into $F_{k} \quad$ select item $_{1}, \ldots$, item ${ }_{k}$, count( $\left.{ }^{\star}\right)$ from $C_{k}$, Xact $t_{1}, \ldots$, Xact $t_{k}$ where $t_{1}$.item = $C_{k}$.item ${ }_{1}$ and ....t. $t_{k}$.item $=C_{k}$.item $k_{k}$ and $t_{1}$.id $=t_{2}$.id and $\ldots . t_{k-1}$.id $=t_{k}$.id group by item $1, \ldots$, item id $_{k}$ having count( $\left.{ }^{*}\right)>$ :minsup

Gambar 5. Penghitungan support $K$-way

Penghitungan support menggunakan data dengan skala menengah ke atas dengan nilai minimum support yang kecil dapat ditangani menggunakan K-way pada bagian support counting. Penggunaan Two Group-by pada proses support counting pada data berskala menengah ke atas tidak dianjurkan karena untuk minimum support dengan nilai yang kecil akan menyebabkan pemrosesan query dengan banyak sorting (misalnya : pada dataset $\mathrm{B}$ dengan minimum support $=0,001$, K-way masih dapat berjalan dengan baik tetapi pada 2 Group-by, algoritma Apriori berhenti tidak normal). Dengan banyaknya sorting menyebabkan temporary segments yang digunakan sebagai area kerja operasi sorting pada tablespace yang ada tidak dapat dikembangkan lagi karena telah mencapai batas maksimal. Sehingga dapat menyebabkan iterasi dalam pengisian tabel $\mathrm{F}$ tidak selesai yang dapat mengakibatkan berhentinya algoritma Apriori secara tidak normal.

Pada akhir iterasi, $\mathrm{C}_{\mathrm{k}}$ diperiksa untuk menentukan kandidat mana yang sering muncul, menghasilkan $\mathrm{F}_{\mathrm{k}}$. Penghitungan support berakhir ketika $F_{k}$ atau $\mathrm{C}_{\mathrm{k}+1}$ kosong.

Untuk menghasilkan rule digunakan tabel RC yang berisi semua kemungkinan rule dari frequentitemset dengan nilai sup > minimum support. Jika nilai minimum support yang diberikan sangat kecil menyebabkan pengisian tabel RC terdiri atas banyak operasi sorting. Hal ini menyebabkan temporary segments yang digunakan sebagai area kerja operasi sorting pada tablespace yang ada tidak dapat dikembangkan lagi karena telah mencapai batas maksimal. Sehingga dapat menyebabkan iterasi dalam pengisian tabel RC tidak selesai yang dapat mengakibatkan berhentinya algoritma Apriori secara tidak normal.

Pembangkitan rule dimulai dengan cara melakukan join antara antecedent dari kandidat rule dengan frequent-itemset untuk mendapatkan support antecedent. Confidence dari rule didapatkan dengan membagi support dari rule dengan support antecedent-nya. Algoritma berakhir setelah pembangkitan rule menghasilkan rule-rule dengan nilai support > minimum support dan confidence > minimum confidence.

\section{Kesimpulan}

Berdasar analisis pengukuran, metode support counting K-way lebih baik daripada 2 Group-by karena operasi sorting dan agregasi pada K-way lebih sedikit dibandingkan Two Group-by sehingga lebih sedikit mengkonsumsi I/O (disk). Besarnya minimum support berbanding terbalik dengan banyak baris record yang diproses. Sedangkan besarnya baris record yang diproses berbanding lurus dengan konsumsi operasi I/O, akses buffer dan elapsed time. K-way mampu dengan baik menangani data berskala menengah ke atas dengan nilai minimum support yang kecil, sedangkan penggunaan 2 Group-by dapat mengakibatkan berhentinya Algoritma Apriori secara tidak normal. Teknik candidate frequent $k$-itemset (candidate generation) merupakan bottleneck dari Algoritma Apriori karena:

a. banyaknya kandidat frequent-itenset yang dihasilkan sebagai input terhadap penghitungan support sangat besar.

b. scan/pembacaan berulang record pada RDBMS

Diperlukan konfigurasi perangkat keras yang mendukung implementasi data mining. Selain itu, pada sisi RDBMS perlu dilakukan tuning pada implementasi data mining, karena sifat data yang dimining biasanya merupakan data berukuran besar. Perlu dilakukan perbaikan terhadap teknik candidate frequent $k$-itemset (candidate generation) yang merupakan bottleneck algoritma Apriori. Dapat dilakukan pengembangan lanjut implementasi Association Rule, yaitu meliputi:

a. dataware housing: OLAP mining

b. data mining yang lain: spatial data, multimedia data, time series data dsb.

\section{Daftar Pustaka}

[1] Agrawal R., T. Imielinski, and A.Swami. 1993. Special Issue on Learning and Discovery in Knowledge Based Databases. Database Mining : A Performance Perspective. IEEE Transactions on Knowledge and Data Engineering, 914-925.

[2] Agrawal R. and R. Srikant. 1994. Fast Algorithms for Mining Association Rules in Large Databases. Research Report RJ 9839. San Jose, CA: IBM Almaden Research Center

[3] Ambarwaty, Retno. 1997. Sistem Pendukung Keputusan Pemasaran Jasa Telepon Dengan Segmentasi Pelanggan Psikografis. Studi Kasus di Kandatel Jakarta Barat. Bandung: Sekolah Tinggi Teknologi Telkom. 
[4] Direct Marketing Association. 1992. Managing Database Marketing Technology for Sucess.

[5] Date, C.J. 1994. An Introduction to Database System. New York: Addison Wesley.

[6] Fayyad, U., G.Piatetsky-Shapiro, and P. Smyth. 1996. From data mining to knowledge discovery : An overview. In Advances in Knowledge Discovery and Data Mining. Cambridge, MASS: AAAI/MIT Press,

[7] Han, Jiawei and M. Kamber. 2000. Data Mining: Concepts and Techniques. Morgan Kaufmann.

[8] Han, Jiawei. Towards On-line Analytical Mining : An Integration of OLAP and Data Mining. Intelligent Systems. Canada: Database Research Lab. DBMiner Technology Inc. and School of Computing Science Simon Fraser University, British Columbia. http://www.dbsummit.com/articles/Han/

[9] Information Discovery, Inc. 1996. Datamines for Dataware Houses.

[10] The Parallel Computer Center. 1995. Data Mining : An Introduction. Student Note. The Queen's University of Belfast.

http://www.pcc.qub.ac.uk

[11] Piatetsky-Shapiro, G., Fayyad, U., and P. Smyth. 1996. The KDD Process for Extracting Useful Knowledge from Volumes of Data. Communications of The ACM, November 1996/Vol. 36, No. 11. ACM

[12] Ramakrishnan, Raghu. 2000. Database Management System. MacGraw Hill.

[13] Sarawagi, S., Thomas S. and R. Agrawal. 1998. Integrating association rules mining with relational database system : Alternative and implications. Research Report RJ 10107 (91923 ). IBM Almaden Research Center.

[14] Silberschatz, Abraham, Henry F. Korth, and S. Sudarshan. 1997. Database System Concepts. The McGraw-Hill Companies, Inc.

[15] Stonebraker, M. 1993 The DBMS research at crossroads. Dublin: Proc. of the VLDB Conference.

[16] Turban, Efrain. 1995. Decision Support System and Expert System, Prentice Hall, Inc.

[17] Yourdon, Edward. 1989. Modern Structured Analysis. Prentice Hall, Inc. 